\title{
Analysis of Land Use/Land Cover Change in Jammu District Using Geospatial Techniques
}

\author{
Dr. Anuradha Sharma ${ }^{1}$, Davinder Singh ${ }^{2}$ \\ ${ }^{1}$ Head, Department of Geography, University of Jammu, Jammu-180006, India \\ ${ }^{2}$ Research Scholar. Department of Geography, University of Jammu , Jammu-180006, India
}

\begin{abstract}
Rapid and extensive modifications of land use/land cover changes due to accelerated human activities have been a major cause of global environmental change in the last one decade. During the past 10 years, humans changed these landscapes to meet the growing demand for food, fodder, timber and fuel more rapidly and extensively than in any comparable period of time. The change is mainly because of shifting to horticulture and agriculture plantations, which are economically beneficial and also due to increasing pressure of population resulting in to a lot of residential and commercial developments. It is an important component for developmental, planning and management activities. The analysis of the district is done by using supervised classification method, under which land use/ land cover is categorised into nine categories viz. Crops, Forests, builtup, Plantation, Scrubs, Fellow land, Water bodies, Barren land and Dry streams. For understanding the impacts of changing physical characteristics on land, geospatial tools like remote sensing and GIS have been useful.
\end{abstract}

Keywords: Land use/Land Cover, Supervised Classification, Satellite Images, and Geospatial Techniques.

\section{Introduction}

The array of information available on land use/Land cover is required to be arranged or grouped under a suitable frame work to facilitate systematic and land use inventory. Land use refers to "man"s activities on land, which are directly related to land." Land cover denotes "the vegetational and artificial constructions covering the land surface". It is the most important natural resource on which all manes activities are based. Several studies have been reported in India on landuse/ landcover classification in which the investigators use the remotely sensed data and analyse that data with the help of Geographical information Techniques. Sharma and Bran (2005) classified seasonal spectral variation on land cover from the satellite imageries. GIS techniques were used to examine the landuse changes in Ashwani khed watershed by Mahajan and pawar (2005). Land use and lancover changes have impacts on a wide range of environmental and landscape attributes including the quality of water, land and air resources, ecosystem process and functions, the climate system itself through greenhouse gas fluxes and surface albedo effects (Balchander D.et.al.2001). The application of remotely sensed data made possible to study the change in land cover in less time, at low cost with better accuracy in association with GIS that provide suitable platform for data analysis, update and retrieval (Chilar 2000). Agriculture has played a key role in the development of human civilization. Until the Industrial Revolution, the vast majority of the human population laboured in agriculture. The type of agriculture they developed was typically subsistence agriculture in which farmers raised most of their crops for consumption on farm, and there was only a small portion left over for the payment of taxes, dues, or trade. Land use applications involve both baseline mapping and subsequent monitoring. Since, the timely information is required to know the current quantity of land which is in use and to identify the land changes from year to year (Kumaraswamy and Narayanakumar, 2005). Land use and land cover change have been recognized as important drivers of global environment change. Land use is influenced by economic, cultural, political, and historical land-tenure factors at multiple scales. Land cover, on the other hand, is one of the many biophysical attributes of the land that affects the ecosystems functioning. The basic requirement for the planning of better landuse, to face the challenges, is the availability of timely, accurate and upto date data at the shortest possible time which can be achieved from various satellite imageries on a cost effective basis.

\section{Study Area}

Jammu is a divisional headquarter and state es winter Capital, popularly known as City of Temples. The study area is located between $32^{\circ} 30^{\prime} 00^{\prime \prime} \& 33^{\circ} 5^{\prime} 00^{\prime \prime}$ North latitude \& between $74^{\circ} 20^{\prime} 00^{\prime \prime}$ and $75^{\circ} 10^{\prime} 00^{\prime \prime}$ East longitude. The district has been administratively divided into 4 Tehsils, namely; Jammu, Akhnoor, R.S.Pura and Bishnah. For development purposes these Tehsils have been further, divided into eight community development blocks like as Khour, Akhnoor, R.S.Pura Bishnah, Satwari, Dansal, Bhalwal, and Marh. The population of the study area is 15.27 lacs as per census of 2011data. 


\section{International Journal of Science and Research (IJSR) \\ ISSN (Online): 2319-7064}

Index Copernicus Value (2013): 6.14 | Impact Factor (2014): 5.611

\section{LOCATION MAP OF THE STUDY AREA}

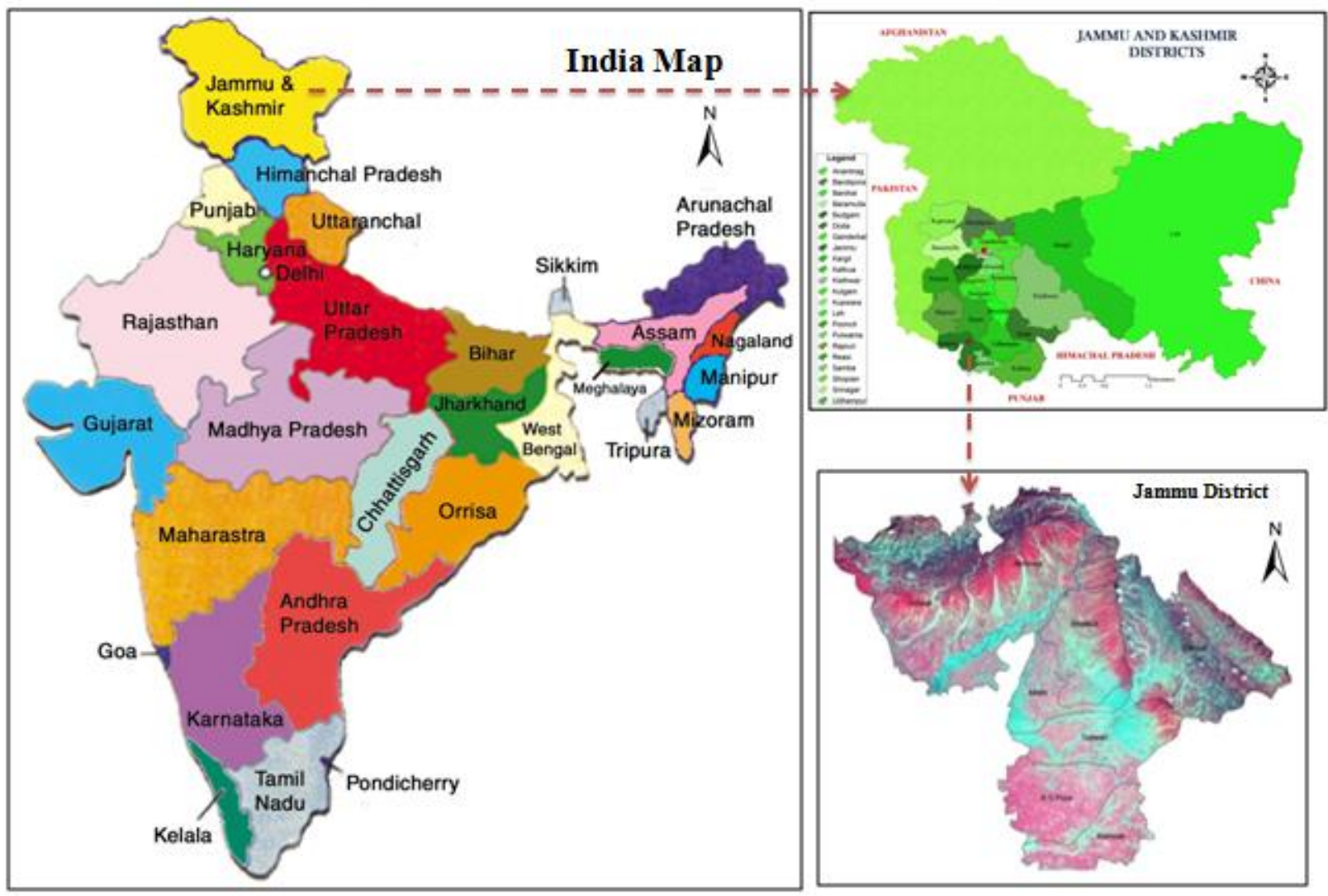

Figure 1: Location map of the study area

The population density is 596 persons $/ \mathrm{km}^{2}$ and the literacy is of the district are highest in the whole state i.e. $83.98 \%$. The total geographical area is $2370 \mathrm{~km}^{2}$ out of which 1165 $\mathrm{km}^{2}$ is covered by hilly terrain and $1205 \mathrm{~km} 2$ is the outer plains. The area lies between 220 to $1180 \mathrm{mts}$ above from the mean sea level.

\section{Objective of the study}

The present Study has been based on the following objectives.

- To identify the existing land use/Land cover of the study area.

- To study the changing pattern of area using Supervised Maximum likelihood method.

- To prepare the classified map of the study area.

\section{Materials and Methods}

The study is based on primary and secondary data. The primary data have been gathered through extensive field survey; whereas the secondary data is collected through Census data from (2001 and 2011). The satellite data has been used to find the change in the study area. Surveys of India toposheets have been used to delineate the area, under studies on a scale of 1:50,000. The satellite data analysis was done by using ERDAS Imagine Software and Land Use Classes map of the area have been prepared by Supervised Classification Using Maximum likelihood method. Field Survey of the area was conducted to collect information related to different land use classes. The GPS (Global Positioning System) instrument was used for collection of ground truth in different time and seasons.

\section{Methodology Flow Diagram}




\section{International Journal of Science and Research (IJSR) \\ ISSN (Online): 2319-7064}

Index Copernicus Value (2013): 6.14 | Impact Factor (2014): 5.611

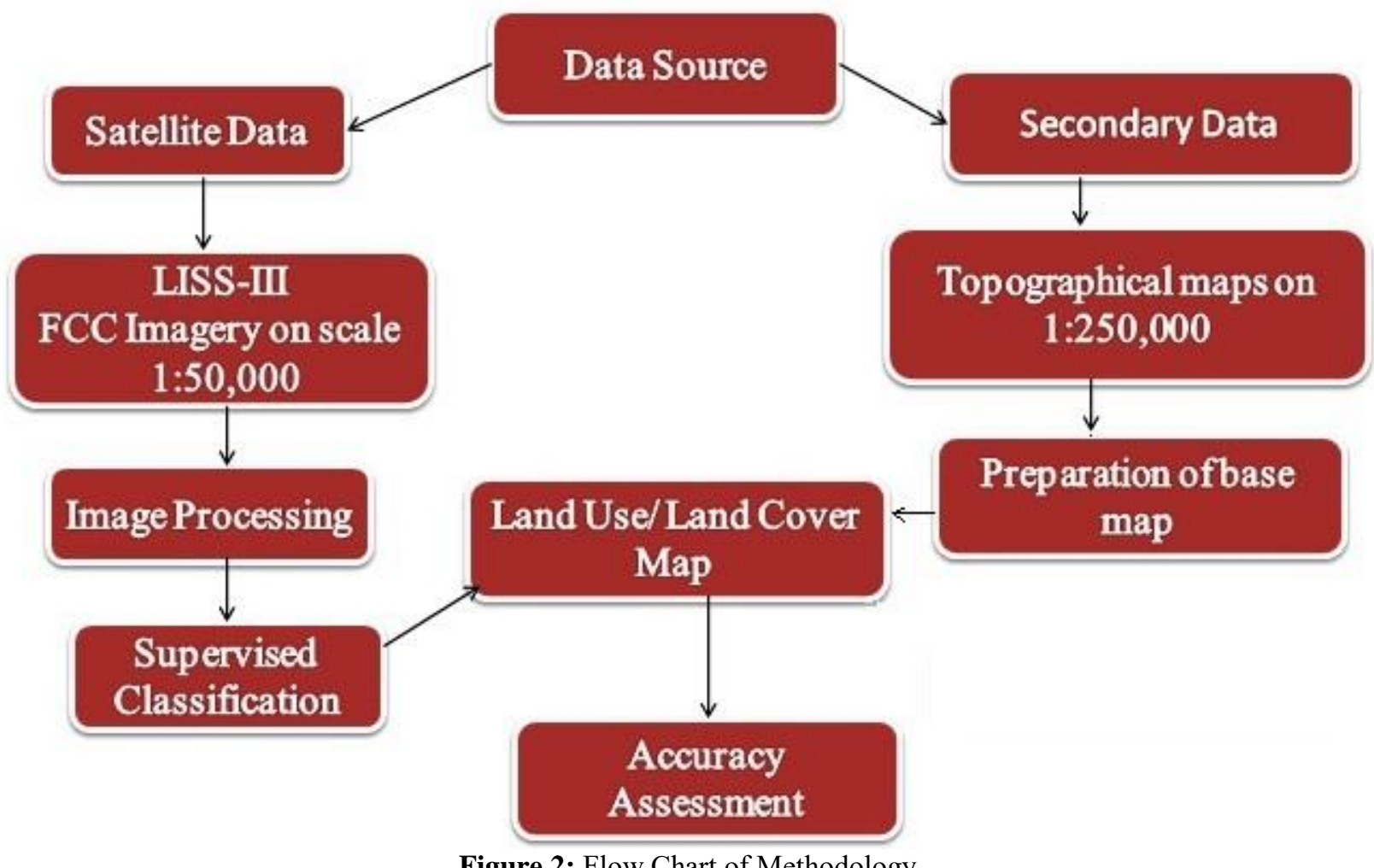

Figure 2: Flow Chart of Methodology

\section{Result \& Discussion}

The study area is focused to analyze the spatial and temporal information of Land use land cover. Supervised classification is performed to produce land use land cover map from IRS Satellite data. Selection of training sites, extraction of Signatures from the image for Classification. In supervised classification the training data extraction was a critical step. All three classifications like Maximum likelihood classification, (MLC) Parallelepiped and minimum distance to mean classification technique was used. It was observed that the Maximum Likelihood classification (MLC) gave the good results as compare to both techniques. After classifications the Accuracy assessment and the degree of Correctness of the map was calculated. Generally there are three major steps involved in the supervised classification procedures as follows: 1. Training stage 2. Classification stage 3. Accuracy assessment.

Land use/Land Cover in Jammu District using Maximum likelihood Classification method of the year 2001 and 201.

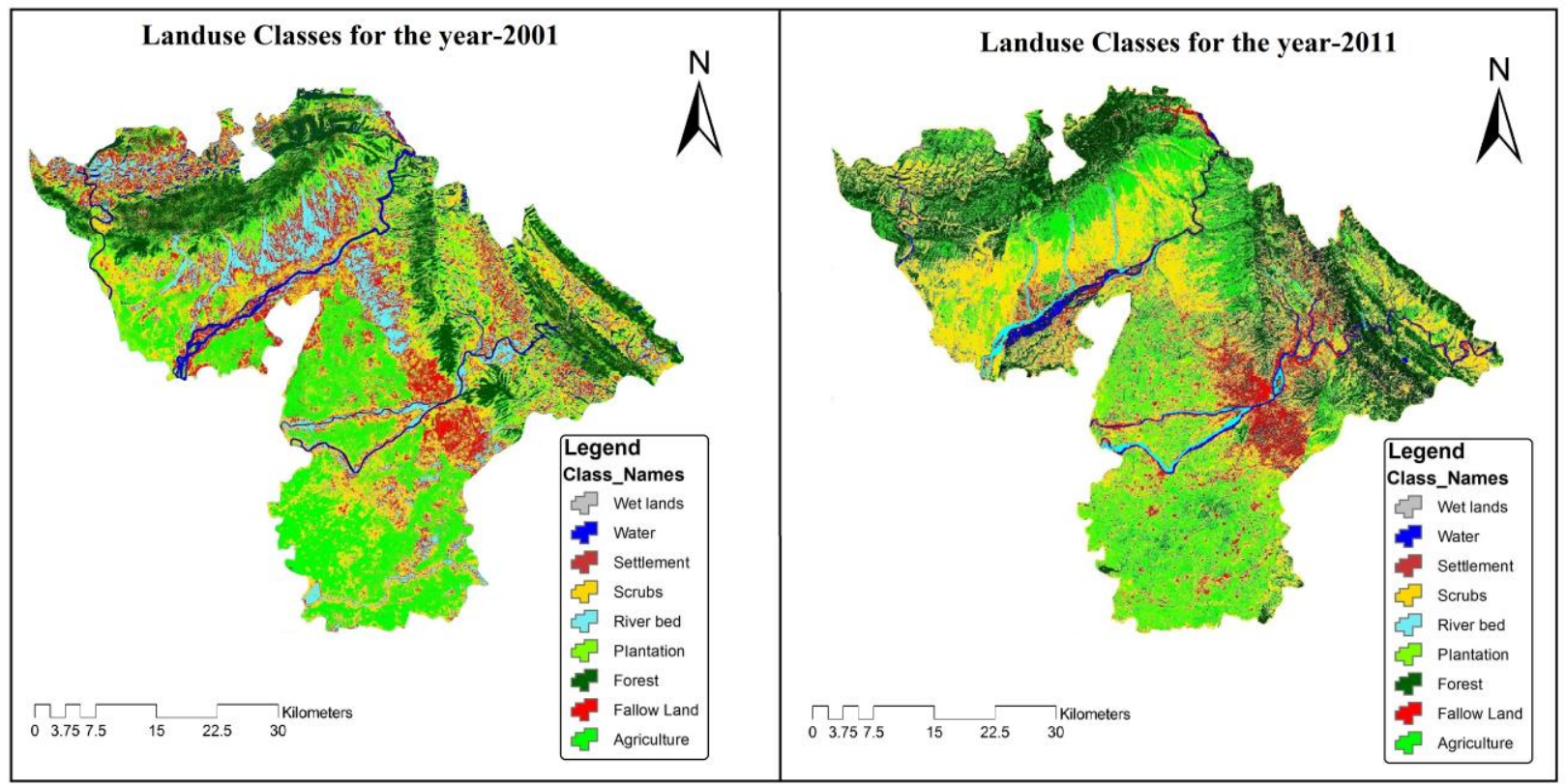

Figure 3: Landuse classes of year 2001 and year 2011 
International Journal of Science and Research (IJSR)

ISSN (Online): 2319-7064

Index Copernicus Value (2013): 6.14 | Impact Factor (2014): 5.611

Table 1: Percentage of area under different Land use classes

\begin{tabular}{|c|c|c|c|}
\hline $\begin{array}{c}\text { Land Use } \\
\text { Classes }\end{array}$ & $\begin{array}{c}\text { (Area in } \\
\text { Percentage) } \\
2001\end{array}$ & $\begin{array}{c}\text { (Area in } \\
\text { Percentage) } \\
2011\end{array}$ & $\begin{array}{c}\text { Percentage } \\
\text { Change } \\
(2001-2011)\end{array}$ \\
\hline Water bodies & 2.7 & 2.5 & -0.2 \\
\hline Settlement & 11.5 & 13.9 & 2.4 \\
\hline River bed & 3.6 & 3.9 & 0.3 \\
\hline Plantation & 5.7 & 6.7 & 1.0 \\
\hline Forest & 11.4 & 11.5 & 0.1 \\
\hline Scrub & 21.7 & 21.6 & -0.1 \\
\hline Fellow land & 23.3 & 21.0 & -2.3 \\
\hline Wet lands & 1.5 & 1.4 & -0.1 \\
\hline Agriculture & 18.6 & 17.5 & -1.1 \\
\hline
\end{tabular}

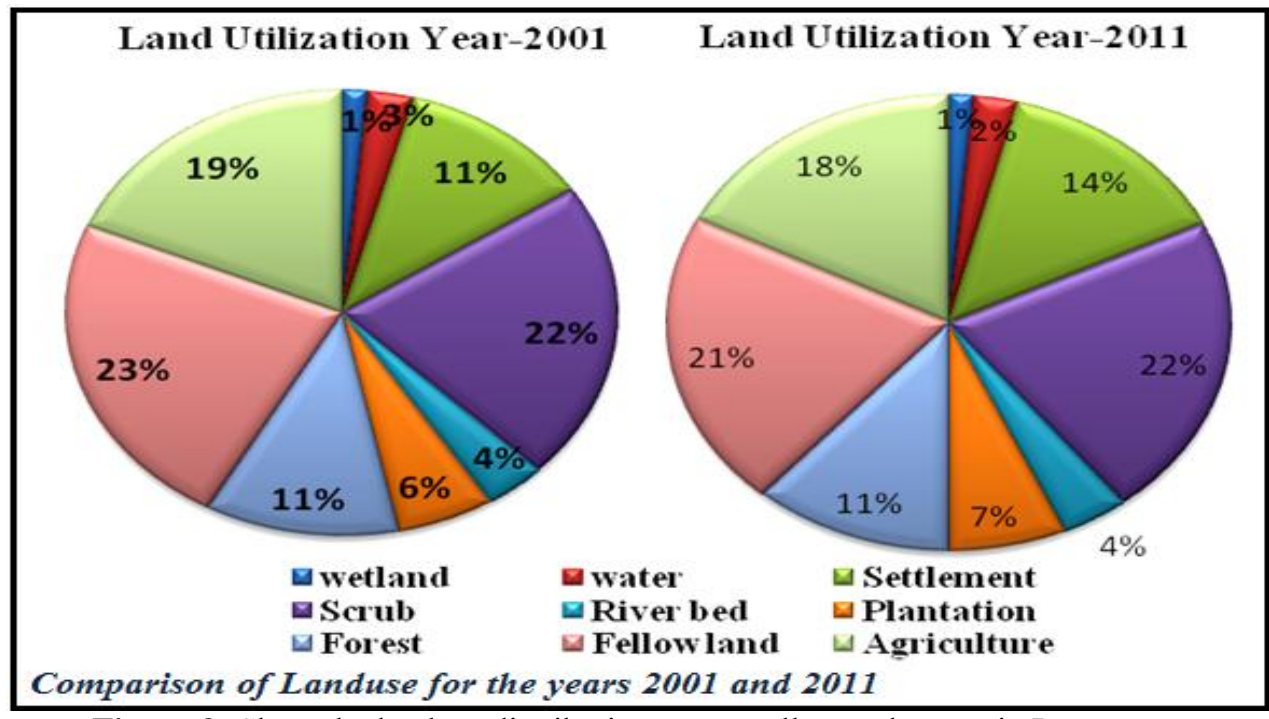

Figure 3: Show the landuse distribution pattern all over the area in Percentage

The static land use land cover distribution for each study year as derived from the satellite data and which is mentioned in the above table. The figures $1 \& 2$ represent the area of each land use land cover classes for two different years. From the table no. 1 it clearly reflects that the major change was occurred in Settlement and fellow land. The following nine classes have being adopted for laduse pattern i.e. 1. Wet lands 2. Water bodies 3. Settlement 4. Scrub 5. River bed 6. Plantation. 7. Forest 8. Fallow land and 9. Agriculture land. The fellow land area is decreased and shows the negative change recorded i.e. $(-2.3 \%)$ where as the settlement area have been increased which shows the positive change recoded i.e. (2.4\%) from the last ten years. The fellow land decreased area have been divided into four classes i.e. settlement, river bed, forest, and plantation. The influence of human inhabitation developed due to nonagricultural activities, like building of houses, schools, industrialisation, Transportation (Railway and Roads network) etc. Last ten years the population pressure is increased in the Jammu city and its adjoining parts. The satellite data of kharif season shows that some agricultural land is marked as fallow land; they were verified during field survey. From period year (2001 to 2011), the settlement increased to $11 \%$ to $14 \%$ and plantation is $6 \%$ to $7 \%$ respectively. The river bed and forest area have shown the minute change. On the other hand fallow land, agriculture land, scrub, wet land and water bodies reduced; which is shown in the pie diagram. The forests of the study area represent typical subtropical vegetation. The lower altitudinal zonation is dominated mainly by shrubs with a few scattered patches of broad-leaved trees. On moderate elevation these shrubs are found to be mixed with broadleaved and chirpine communities, while high elevations are dominated exclusively by chirpine patches. The population pressure is increased in the city heart due to the migration of people from Valley (i.e. Kashmiri migrants), and other Jammu province districts such like as Doda, Rajouri, and Poonch. Thus the research paper is focused on land use pattern using geospatial techniques to analyze the satellite data mapping and detect changes under study area; using two different period images. This therefore suggests that the rate at which new lands are acquired for development is higher.

\section{Classification Accuracy Assessment}

Classification process is not complete until its accuracy is assessed. Accuracy assessment can be performed by comparing two sources of information (Jensen, 1996)

- Remote-sensing derived classification data and

- Reference test data.

The classification accuracy requires the collection of some in situ data or prior knowledge about some parts of the terrain which can be compared with remote sensing derived classification map. Classification is necessary to compare two classification maps 1) remote sensing derived map and 2) assumed true map. From the year 2001 the Overall classification is $75.79 \%$ and year 2011 the overall classification is $83.33 \%$ as given in the below tables. 


\section{International Journal of Science and Research (IJSR) \\ ISSN (Online): 2319-7064}

Index Copernicus Value (2013): 6.14 | Impact Factor (2014): 5.611

Table 2: Accuracy Assessment (year-2001)

\begin{tabular}{|c|c|c|c|c|c|}
\hline Classes & References & Classified & No. Correct & Producer's Accuracy & User's Accuracy \\
\hline Wet lands & 23 & 19 & 16 & $69.57 \%$ & $84.21 \%$ \\
\hline Water bodies & 18 & 23 & 16 & $88.89 \%$ & $69.57 \%$ \\
\hline Settlement & 25 & 23 & 21 & $84.00 \%$ & $91.30 \%$ \\
\hline Scrub & 20 & 18 & 17 & $85.00 \%$ & $94.44 \%$ \\
\hline River bed & 23 & 22 & 15 & $65.22 \%$ & $68.18 \%$ \\
\hline Plantation & 15 & 17 & 12 & $80.00 \%$ & $70.59 \%$ \\
\hline Forest & 23 & 18 & 14 & $60.87 \%$ & $77.78 \%$ \\
\hline Fellow land & 21 & 26 & 17 & $80.95 \%$ & $65.38 \%$ \\
\hline Agriculture & 22 & 24 & 16 & $72.73 \%$ & $66.67 \%$ \\
\hline Total & 190 & 190 & 144 & & \\
\hline
\end{tabular}

Overall Classification Accuracy $=75.79 \%$

Table 3: Accuracy Assessment (Year-2011)

\begin{tabular}{|c|c|c|c|c|c|}
\hline Classes & References & Classified & No. Correct & Producer's Accuracy & User's Accuracy \\
\hline Wet lands & 17 & 22 & 14 & $82.35 \%$ & $63.63 \%$ \\
\hline Water bodies & 21 & 19 & 17 & $80.95 \%$ & $89.47 \%$ \\
\hline Settlement & 23 & 20 & 18 & $78.26 \%$ & $90.00 \%$ \\
\hline Scrub & 19 & 24 & 18 & $94.73 \%$ & $75.00 \%$ \\
\hline River bed & 21 & 22 & 19 & $90.47 \%$ & $86.36 \%$ \\
\hline Plantation & 20 & 22 & 17 & $85.00 \%$ & $77.27 \%$ \\
\hline Forest & 27 & 18 & 17 & $62.96 \%$ & $94.44 \%$ \\
\hline Fellow land & 22 & 24 & 20 & $90.90 \%$ & $83.33 \%$ \\
\hline Agriculture & 28 & 27 & 25 & $89.28 \%$ & $92.59 \%$ \\
\hline Total & 198 & 198 & 165 & & \\
\hline
\end{tabular}

Overall Classification Accuracy $=83.33 \%$

The overall accuracy classification can be computed from the error of matrix. An error of matrix expresses several characteristics about classification performance. When studying the various classification the error of Omission (exclusion) and Commission (inclusion). All the non diagonal elements of the matrix represent errors of omission or commission.

\section{Conclusion}

The present study of the land use land cover mapping of the study area will also help in management of the land use and land cover categories. The Geospatial techniques have proved successful in providing a comprehensive, reliable and up-to date information on landuse. The Supervised classification technique of the images has been successful to study the percentage change in land use and land cover to the study area. The major change occurred in the Settlement area and Plantation, in which settlement area is increased $11 \%$ to $14 \%$ and Plantation area is increased $6 \%$ to $7 \%$. On the other hand the Fallow land is decreased $23 \%$ to $21 \%$ and Agriculture area is decreased $19 \%$ to $18 \%$ respectively. After classification the accuracy assessment has been calculated, which reflects that the overall accuracy of year 2001 is $75.79 \%$ and the year 2011 is $83.33 \%$.

\section{References}

[1] Chilar J .(2000). "Land cover mapping of large areas from satellite: status and research priorities", International Journal of Remote Sensing, Vol.63, No.9, pp.913-918.

[2] Arora, M K and Agarwal, K. (2002). A program for sampling design for image classification accuracy assessment photogrammetry Journal of Finland, vol.18, No.1, pp33-43.

[3] Sharma D.P and Bran L. (2005). Effect of seasonal spectral variation and landcover classification. Indian Journal of Remote Sensing. 33, 2, 203-209.

[4] Balchandar, D., Rutharvel Murthy, K., Muruganadam, $\mathrm{R}$, et.al (2011). Analysis of land use/ Land cover using remote sensing techniques-A case study of karur District, Tamil Nadu, India, International Journal of current Research, Vol.3, No.12, pp 226-229.

[5] Narayanakumar, R. and Kumaraswamy, K. (2006). „Land use and land cover in Oussudu lake environs: A remote sensing based study, The Deccan geographer, 44 (1), pp 43-50.

[6] Mahajan S, Pawar P (2005). Landuse Changes in Ashwani Khed watershed using GIS techniques. Indian Journal of Remote Sensing, 33, 2, 227-232.

[7] Jensen, J.R. (1996), Introductory Digital Image Processing: A Remote Sensing Perspective. $2^{\text {nd }}$ Edition. Upper Saddle River: Prentice Hall.

\section{Author Profile}

Dr. Anuradha Sharma is Head, Department of Geography, University of Jammu, Jammu-180006, India

Davinder Singh Manhas is Research Scholar, Department of Geography, University of Jammu, Jammu-180006, India 